\title{
Patentability of Self-Replicating Technologies
}

\author{
Richard H. Shear \\ Posz Law Group, Reston, Virginia 20191 \\ Correspondence: rshear@poszlaw.com
}

\begin{abstract}
Patents provide an incentive to inventors, investors, and entrepreneurs to conduct research and development, especially in risky (i.e., unpredictable) fields of technology. This review discusses whether self-replicating technologies are patentable within the United States and the issues surrounding them. Self-replicating technologies discussed include plants, bacteria, and genetic technology and the historical legal precedents that have led to the current status of the patent law. To clearly understand these issues, the review also discusses various U.S. Supreme Court cases that, although not related to self-replicating technologies, have an impact on these patentability issues. Finally, some thoughts regarding patent strategy are presented so as to maximize patent protection for these technologies.
\end{abstract}

\section{WHAT CAN BE PATENTED}

\begin{abstract}
A patent is a grant from the government to Ainventors. It grants the inventor the exclusive right to make, use, offer to sell, or sell any patented invention within the United States or import into the United States any patented invention during the term of the patent (35 U.S.C. $\$ 271)$. For a patent to be granted, the invention must be new, useful, and not obvious from the prior art (35 U.S.C. $\$ \$ 101-103$ ). Furthermore, the invention must relate to any new and useful process, machine, manufacture, or composition of matter or any new and useful improvement thereof (35 U.S.C. \$101). When reading a patent, it should be noted that the right granted to the inventor is to exclude others from making, using, selling, etc., what is described only in the claims of the patent.
\end{abstract}

\section{CAN SELF-REPLICATING TECHNOLOGIES BE PATENTED?}

Are self-replicating technologies eligible to be patented? Should self-replicating technologies be eligible to be patented? Should living things be eligible to be patented? Frequently, these questions are thought of on an emotional level. Often, society thinks of such technologies differently from other technologies. Why, however, should that be the case?

To advance scientific development, the patent law was enacted. This incentive to spur invention was recognized early in American history. In fact, the drafters of the United States Constitution recognized that providing an incentive to innovators would help spur innovation. Accordingly, Article 1, Section 8 of the U.S. Constitution grants Congress the power

Editors: Salim Mamajiwalla and Rochelle Seide

Additional Perspectives on Intellectual Property in Molecular Medicine available at www.perspectivesinmedicine.org

Copyright (C) 2015 Cold Spring Harbor Laboratory Press; all rights reserved; doi: 10.1101/cshperspect.a021071

Cite this article as Cold Spring Harb Perspect Med 2015;5:a021071 
R.H. Shear

To promote the progress of science and the useful arts, by securing for limited times to authors and inventors the exclusive right to their respective writings and discoveries.

Note that the Constitution did not limit the types of scientific developments that were eligible to be patented.

In the early days of the country, the inventions tended to be mechanical in nature. It is estimated that $\sim 10,000$ patents were granted in the United States from July 1790 to July 1836. The patents included one for a grate, potash production, and the cotton gin. Clearly, such inventions did not include self-replicating technologies, and such issues were not litigated in those days.

In 1952, Congress exercised its power to "promote the progress of science and the useful arts" by enacting Title 35 of the United States Code, otherwise commonly called the "patent law." In many aspects, this statute was a codification of existing patent law. The patent law defines what inventions are eligible to be patented.

35 U.S.C. $\$ 101$ describes what can be patented:

Whoever invents or discovers any new and useful process, machine, manufacture, or composition of matter, or any new and useful improvement thereof may obtain a patent therefor, subject to the conditions of this title.

Note that, like the founding fathers, Congress did not limit the types of scientific developments that were eligible to be patented. 35 U.S.C. $\$ 101$ appears to be rather expansive as to what can be patentable subject matter. For many years, the meaning of 35 U.S.C. $\$ 101$ was rarely questioned. As inventions became more diverse and sophisticated, the meaning of $\$ 101$ came under scrutiny. This was especially true as inventors discovered ways to improve technologies that self-replicate, for example, living organisms. Such scrutiny resulted in the enactment of two pieces of legislation that provide "patent-like" protection.

\section{THE PLANT PATENT ACT}

In 1930, Congress enacted the Plant Patent Act, which established patent protection for developers of new varieties of plants produced by asexual propagation. Examples of such plants include rose bushes propagated by cutting the stems from one rose bush and using that cutting to alter another rose variety. Patents obtained under this section of the law are referred to as "plant patents," whereas patents obtained under the remaining part of the law are referred to as "utility patents."

The current Plant Patent Act, 35 U.S.C. $\$ 161$, states:

Whoever invents or discovers and asexually reproduces any distinct and new variety of plant, including cultivated sports, mutants, hybrids, and newly found seedlings, other than a tuber propagated plant or a plant found in an uncultivated state may obtain a patent therefor, subject to the conditions and requirements of this title.

The act protects the inventor by excluding others from reproducing, selling, or using a plant so reproduced. Note that the act excludes potatoes, as they are a tuber-propagated plant. To be eligible for protection, the newly invented plant must be stable and produced by asexual means. Asexual means includes, but is not limited to, root cuttings, grafting, bulbs, division, tissue culture, rhizomes, and the like. The patent application must include a specification that contains a full and complete botanical description of the plant, as reasonably as possible, and the characteristics that distinguish it from known and related plants.

\section{THE PLANT VARIETY PROTECTION ACT}

The Plant Variety Protection Act (PVPA) was enacted in 1970 to provide breeders exclusive control of new, distinct, uniform, and stable sexually reproduced or tuber-propagated plant varieties. Note that tuber-propagated plants, which were not protectable under the Plant Patent Act, are covered. Note also that this act, 7 U.S.C. $\$ \$ 2321-2582$, covers plant varieties that are sexually reproduced, as opposed to the Plant Patent Act, which covers those plant varieties 
that are asexually reproduced. The PVPA is not administered by the U.S. Patent and Trademark Office (USPTO), but by the U.S. Department of Agriculture.

For a certificate to be obtained, the variety must be new; that is, it cannot have been sold in the United States for $>1$ yr prior to the filing of the application or $>4 \mathrm{yr}$ in a foreign country. The variety must be distinct, that is, clearly distinguishable from known plant varieties. Additionally, it must be uniform; that is, any variations must be describable, predictable, and commercially acceptable. Finally, it must be stable; that is, when reproduced, it must remain unchanged.

The PVPA provides certain exemptions to those who may reproduce a covered plant variety. For example, the U.S. Department of Agriculture may provide for compulsory licensing if it is deemed to be in the "public interest" to ensure an adequate supply of food, fiber, or feed and the owner is unwilling or incapable of doing so. In addition, the use of a protected variety in bona fide research is exempted. Such exemptions have led, as we shall see, to the desire to obtain utility patents for plants, whether sexually or asexually produced. These exemptions have led those involved in expensive and timeconsuming research to improve self-replicating technologies to look for other ways to protect their investment.

\section{UTILITY PATENTS FOR LIVING THINGS}

If asexually propagated plants can be protected by the Plant Patent Act and sexually propagated plants can be protected by the PVPA, can such inventions be protected by utility patents? This question was indirectly addressed when a microbiologist, Ananda Mohan Chakrabarty, working for General Electric filed a patent application directed to a bacterium that was capable of breaking down oil components. It was said to be particularly useful for cleaning up oil spills. The patent application included claims to a process for producing the bacterium, an inoculum comprising a carrier material floating on water, and finally, claims to the bacterium itself.
The USPTO rejected the claims to the bacterium on two grounds. First, it held that the bacteria were "products of nature," which are not eligible to be patented. Second, it held that living things are not patentable subject matter under 35 U.S.C. $\$ 101$.

Chakrabarty appealed to the USPTO Board of Appeals. The Board held that 35 U.S.C. $\$ 101$ did not extend to living things created in the laboratory. Chakrabarty then appealed to the Court of Customs and Patent Appeals, the predecessor court to the Court of Appeals for the Federal Circuit (CAFC). In a rather circuitous line of cases, this court held that living things could be patented.

The USPTO then appealed to the U.S. Supreme Court. The court took the case to decide specifically if a microorganism, such as a bacterium, constitutes a manufacture or composition of matter within the meaning of the patent law.

The case, Diamond v. Chakrabarty (447 U.S. 303) (1980), reviewed patent law in the United States dating back to 1793 . In doing so, the court reviewed the writings of Thomas Jefferson, patent statutes in the 1800s, and legislative history, especially the legislative history of the 1952 act that created Title 35 . In congressional committee reports that accompanied the 1952 act, it became clear that Congress intended statutory subject matter to "include anything under the sun that is made by man" (S. Rep. No. 1979, 82d Cong., 2d Sess., 5 (1952); H.R. Rep. No. 1979, 82d Cong., 2d Sess., 6 (1952)).

The Supreme Court held in the Chakrabarty case that living things can be patented as utility patents. The court stated that Congress had the authority to amend the law to exempt such inventions from patent eligibility should it so desire, but had not done so. The court did note that 35 U.S.C. $\$ 101$ is not unlimited. Certain things are not eligible to be patented. These include products of nature, laws of nature, physical phenomena, and the like. Accordingly, it noted that Einstein could not patent $\mathrm{E}=\mathrm{mc}^{2}$. Newton could not patent gravity.

The Chakrabarty case is the seminal case in the field of biotechnology patent law, which up until this past year seemed to have been settled law. 
R.H. Shear

\section{UTILITY PATENTS FOR PLANTS}

After Chakrabarty it became clear that an invention was not ineligible to be patented merely because it was a "living" thing. In many ways, the Chakrabarty case led to an explosion in biotechnology research and investment in both the plant and mammalian fields.

In the plant field, those investing vast sums looked at the protection available, that is, the Plant Patent Act and the PVPA, and noted the weaknesses inherent in those systems. The Plant Patent Act only covered asexual propagation. The PVPA provided various exemptions that reduced its value. Accordingly, investors in plant transformation research, whether it be through conventional breeding or recombinant DNA techniques, looked to the patent law for protection by filing applications to obtain utility patents covering transformed plants.

Pioneer Hi-Bred International, Inc. manufactures inbred and hybrid seed. Pioneer held 17 utility patents that covered such seed. Pioneer sold that patented seed under a label license that allowed the purchaser only the right to produce grain and/or forage. The license prohibited using such seed for propagation, seed multiplication, or the development of a new variety. J.E.M. Ag Supply, Inc. bought patented seed in bags bearing the label license and resold them. Pioneer filed a patent infringement suit. J.E.M. defended on the basis that Pioneer's corn plants are not patentable subject matter within the meaning of 35 U.S.C. $\$ 101$. J.E.M. argued that the PVPAwas the exclusive manner of protection for such plants. The Supreme Court held that newly developed plant breeds fall within the scope of 35 U.S.C. $\$ 101$ (J.E.M. Ag Supply, Inc., dba Farm Advantage, Inc., et al. v. Pioneer HiBred International, Inc. (99-1996) 534 U.S. 124 (2001)).

This issue arose once again regarding Roundup Ready ${ }^{\circledR}$ (RR) soybeans produced and patented by Monsanto Company. RR soybeans were developed by Monsanto to contain a gene that protects the soybeans from being killed by the application of glyphosate herbicide. Glyphosate is the active ingredient in Roundup ${ }^{\circledR}$ herbicide. Monsanto sold RR soybeans only in conjunction with the execution of a license agreement wherein the purchaser agreed not to save such patented seed and replant those seeds in subsequent seasons. The product was sold with a price for the seed and a royalty for the patent license.

Vernon Hugh Bowman purchased commodity soybeans to avoid paying any royalty for Monsanto's RR soybeans. Because Monsanto had a large market share of all soybeans sold in the United States, Bowman believed that the commodity soybeans would include RR soybeans. So Bowman planted the soybean seeds and then applied glyphosate-based herbicide to determine which, if any, of those seeds were RR soybeans. Having sorted out the RR soybeans, Bowman then replanted the RR soybeans year after year. Monsanto sued, claiming that the soybean seeds Bowman saved and replanted infringed its utility patents.

Bowman argued that Monsanto's patent rights were exhausted when the first sale of RR soybeans was made. Monsanto countered by stating that the patent protection is applicable to each generation of soybeans that contain the patented gene. The Supreme Court held that Monsanto's patents were not exhausted and that each new generation of seed was a new product covered by the patent (Bowman v. Monsanto Co. et al. (657 F.3d 1341) (2013)). The court held that the fact that a patented technology can replicate itself does not give a purchaser the right to use replicated copies of the technology.

Note that the Bowman v. Monsanto decision not only provides emphasis that such self-replicating technologies are eligible to be patented, but also implies that including reasonable limitations in a license agreement is valid.

\section{PATENT ELIGIBILITY FOR GENE (DNA) TECHNOLOGY}

In the 1980s, with the advent of recombinant DNA technology, the biotechnology industry as we know it today began to flourish. More and more companies, universities, and governmental agencies conducted research in the manipulation, recombination, of DNA. In 1980, 
Stanford University patented a technique for recombining DNA, the Cohen-Boyer patent, U.S. Patent No. 4,237,224. Claim 1 of that patent reads:

A method for replicating a biologically functional DNA, which comprises:

transforming under transforming conditions compatible unicellular organisms with biologically functional DNA to form transformants; said biologically functional DNA prepared in vitro by the method of:

(a) cleaving a viral or circular plasmid DNA compatible with said unicellular organism to provide a first linear segment having an intact replicon and termini of a predetermined character;

(b) combining said first linear segment with a second linear DNA segment, having at least one intact gene and foreign to said unicellular organism and having termini ligatable to said termini of said first linear segment, wherein at least one of said first and second linear DNA segments has a gene for a phenotypical trait, under joining conditions where the termini of said first and second segments join to provide a functional DNA capable of replication and transcription in said unicellular organism;

growing said unicellular organisms under appropriate nutrient conditions; and

isolating said transformants from parent unicellular organisms by means of said phenotypical trait imparted by said biologically functional DNA.

This patent was widely licensed and was the "kick start" of the biotechnology revolution.

Oddly enough, roughly 20 years later, a patent application involving a technology having nothing to do with DNA would have an impact on the patent eligibility of self-replicating technology. Indeed, there is a series of Supreme Court cases discussed below that have resulted in a new understanding of whether self-replicating technologies can be patented.

\section{STATE STREET}

In 1993, the Signature Financial Group, Inc. obtained a patent to a method for monitoring
Patentability of Self-Replicating Technologies

and recording the information flow and data and making all calculations necessary for maintaining a partnership portfolio and partner fund, U.S. Patent No. 5,193,056. Claim 1 reads as follows:

A data processing system for managing a financial services configuration of a portfolio established as a partnership, each partner being one of a plurality of funds, comprising:

(a) computer processor means for processing data;

(b) storage means for storing data on a storage medium;

(c) first means for initializing the storage medium;

(d) second means for processing data regarding assets in the portfolio and each of the funds from a previous day and data regarding increases or decreases in each of the funds, assets and for allocating the percentage share that each fund holds in the portfolio;

(e) third means for processing data regarding daily incremental income, expenses, and net realized gain or loss for the portfolio and for allocating such data among each fund;

(f) fourth means for processing data regarding daily net unrealized gain or loss for the portfolio and for allocating such data among each fund; and

(g) fifth means for processing data regarding aggregate year-end income, expenses, and capital gain or loss for the portfolio and each of the funds.

State Street Bank and Trust Co. brought a declaratory judgment action asserting, among other things, invalidity of the Signature patent. State Street argued that the claims were not patentable subject matter covered by $\$ 101$. The district court held that the claimed subject matter fell into one of the exceptions to statutory subject matter, the "mathematical algorithm" exception or the "business method" exception. Thus, State Street argued that the patent sought to protect a business method, which was thought at the time to not be patentable subject matter.

On appeal to the CAFC, the court dismissed the business method exception to patentability 
R.H. Shear

and held that such patents were eligible to be patented (State Street Bank \& Trust v. Signature Financial Group (149 F.3d 1368) (Fed. Cir. 1998)).

Not surprisingly, after the State Street decision, the number and types of patent applications filed to "business methods" exploded. This eventually led to a review of the patent eligibility for so-called business methods in a series of cases known as In re Bilski.

\section{BUSINESS METHOD PATENT ELIGIBILITY}

In 1997, Bernard Bilski filed a patent application claiming a business method for managing financial risk. Claim 1 reads:

A method for managing the consumption risk costs of a commodity sold by a commodity provider at a fixed price comprising the steps of:

(a) initiating a series of transactions between said commodity provider and consumers of said commodity wherein said consumers purchase said commodity at a fixed rate based on historical averages, said fixed rate corresponding to a risk position of said consumers;

(b) identifying market participants for said commodity having a counter-risk position to said consumers; and

(c) initiating a series of transactions between said commodity provider and said market participants at a second fixed rate such that said series of market participant transactions balances the risk position of said series of consumer transactions.

The application was rejected by the USPTO. Bilski appealed to the CAFC. The Federal Circuit reviewed the patent eligibility issue for business methods and created what has been called the "machine-or-transformation test." Basically, a method is eligible to be patented if the method is either (1) tied to a machine or (2) transforms an article to something else or to a different state (In re Bilski (88 U.S.P.Q.2d 1385) (Fed. Cir. 2008)). The court held that processes are not patentable if they are trying to patent an abstract idea or reduce a concept to a mathematical formula.
On appeal to the Supreme Court, the court held that the machine-or-transformation test was not the only test available to decide whether a method claim like that in Bilski was patentable subject matter (Bilski et al. v. Kappos, Undersecretary of the Department of Commerce for Intellectual Property and Director, Patents and Trademarks (103 S. Ct. 3218) (2010)). Unfortunately, the court did not provide much guidance regarding other tests to determine patentable subject matter.

So, why are these "business method" cases relevant to patent eligibility questions regarding biotechnology and self-replicating technologies?

\section{THE PROMETHEUS CASE}

It was in this environment regarding patent eligibility issues that the Prometheus case came to the forefront. Although the technology involved in this case is not directly related to self-replicating systems, anyone desirous of understanding issues related to patent eligibility should be aware of this case.

Prometheus Laboratories was the exclusive licensee of two patents concerning a certain diagnostic test. An exemplary claim was as follows:

A method of optimizing therapeutic efficacy for treatment of an immune-mediated gastrointestinal disorder, comprising:

(a) administering a drug providing 6-thioguanine to a subject having said immune-mediated gastrointestinal disorder; and

(b) determining the level of 6-thioguanine in said subject having said immune-mediated gastrointestinal disorder, wherein the level of 6-thioguanine less than $\sim 230$ pmol per $8 \times 10^{8}$ red blood cells indicates a need to increase the amount of said drug subsequently administered to said subject and wherein the level of 6-thioguanine greater than $\sim 400$ pmol per $8 \times 10^{8}$ red blood cells indicates a need to decrease the amount of said drug subsequently administered to said subject.

In June 2004, Prometheus sued Mayo Collaborative Services, claiming infringement of the two 
patents referred to above. The district court held the patents to be invalid as claiming subject matter that is not patentable under 35 U.S.C. $\$ 101$. The court stated that the first two steps of the method were just "data-gathering" while the third step was an unpatentable mental step.

Prometheus appealed, and in September 2009, the Federal Circuit reversed the district court finding that the claims were patentable. The Federal Circuit found that the method steps were not just "data gathering" but rather that they called for two physical transformations. The first step of administering the drug to the patient transforms the patient. The second step measures the metabolites, which also involves transformations. The Federal Circuit relied on its own decision in In re Bilski, supra. Mayo appealed to the Supreme Court. The Supreme Court remanded the case back to the Federal Circuit to review the case in view of its decision in Bilski, supra. The Federal Circuit did so and reaffirmed its decision holding that the claims did, indeed, call for a transformation and were, therefore, patentable. Once again, Mayo appealed to the Supreme Court.

The Supreme Court held that the claims of the patents were not patentable subject matter. It said that the act of correlating thiopurine (thioguanine) levels was conventional or obvious. A claimed process must do more than teach users how to apply a natural law. The court held that the conventional or obvious use of a product of nature or natural law renders a claim as being not patentable subject matter (Mayo Collaborative Services, dba Mayo Medical Laboratories, et al. v. Prometheus Laboratories, Inc. (No. 10-1150 decided March 20, 2012)).

Many believe the Prometheus decision fundamentally changed patent eligibility and was decided wrongly. They argue that the claims in Prometheus were eligible to be patented. Perhaps the claimed method was obvious, but it was patentable subject matter.

\section{PATENTABILITY OF ISOLATED DNA}

As noted above, it was in this environment that the Supreme Court was asked to decide if claims to isolated DNA are eligible to be patented.
For more than 30 years, applicants have been obtaining claims to DNA that has been isolated, perhaps from nature. It was not uncommon to face a rejection from the USPTO under 35 U.S.C. $\$ 103$ as to the obviousness of such a claim; however, the fact that such claims were eligible to be patented has not often been contested. That, however, changed. Myriad Genetics, Inc. owned several patents containing claims to isolated DNA. The claims cover isolated human genes, BRCA1 and BRCA2, and various alterations thereof that are associated with a predisposition to breast and ovarian cancer. The following claim is typical of the claims involved in those patents:

An isolated DNA coding for a BRCA1 polypeptide, said polypeptide having the amino acid sequence set forth in SEQ ID NO:2.

Various plaintiffs, including the Association for Molecular Pathology, brought suit against Myriad, arguing that such claims are not eligible to be patented under 35 U.S.C. \$101. Also challenged were method claims for detecting an alteration in the BRCA1 gene. The lawsuit made its way to the Federal Circuit, which held that such claims are eligible to be patented (Association of Molecular Pathology v. United States Patent and Trademark Office and Myriad (653 F.3d 1329) (2012)). When appealed to the Supreme Court, the case was remanded back to the Federal Circuit to reconsider in light of the Prometheus case. The sole issue to be determined was whether such claims were eligible to be patented under 35 U.S.C. $\$ 101$. The argument made by the plaintiffs was that such claims were trying to protect "products of nature," which are not eligible to be patented under 35 U.S.C. \$101. On remand, the Federal Circuit held that the claims were not claiming "products of nature" (Association for Molecular Pathology v. United States Patent and Trademark Office and Myriad (689 F.3d 1303) (2012)). The plaintiffs argued that the isolated DNA claims were not "markedly different from the native DNA.” Under Prometheus, the plaintiffs asserted that the differences did not add up "enough" to render them patenteligible. The Federal Circuit once again held that such isolated DNA claims are eligible to be pat- 
R.H. Shear

ented. The court discussed the differences between the isolated DNA, which has been cleaved and is freestanding, and the native DNA, which is intertwined with various proteins to create a complex chemical structure.

On appeal to the Supreme Court, the court held that naturally occurring DNA is not patentable merely because it has been isolated ( $A s$ sociation for Molecular Pathology v. Myriad Genetics, Inc. (569 U.S. 12-398) (2013)). It further held that complementary DNA is patentable subject matter. The court stated that Myriad had not altered or significantly changed the native DNA, but merely found the importance that the DNA played, that is, a significant and valuable property of the DNA. Citing Funk Brothers Seed Co. v. Kalo Inoculant (333 U.S. 127) (1948), the court stated that the discovery of an important property does not make it patentable subject matter. The act of cleaving the DNA and isolating it does not render it to be patentable subject matter. The court held that complementary DNA is patentable because it is not the same as the native DNA in that its creation results in an exon-only molecule. Finally, the court noted that the case did not involve method claims directed to the use of such DNA or genes, nor did it involve DNA that has been altered.

\section{SUMMARY AND RECOMMENDATIONS}

The Supreme Court has been very active in asserting its authority in the patent field during the last 15 years. This is especially true with respect to biotechnology and self-replicating technologies. So, going into 2014, we can more clearly predict what type of patent protection one can obtain for such technology.

Plants produced by asexual propagation techniques can be patented under the Plant Patent Act. Plants produced by sexual propagation may be protected under the Plant Variety Protection Act. Sexually produced plants can be patented as utility patents as well. These plants are typically produced by conventional breeding or plant transformation techniques through re- combinant DNA technology. Because they are new varieties, they are not "products of nature" and should not be rejected from patenting as being ineligible under 35 U.S.C. \$101. Of course, whether any particular plant would be considered to be obvious under 35 U.S.C. $\$ 103$, and hence not patentable, must be determined on a case-by-case basis. To ensure maximum patent protection, in addition to claims to the plants per se, claims to methods for producing such plants and using them for their intended purpose should be considered.

Obtaining patents for DNA or genes has become more problematic. Obtaining patent protection for DNA or genes per se that have been altered from their native state appears to be available. As noted above regarding plants, care should be taken to provide evidence that such genes or DNA are not obvious from the prior art. Developing data to show that such genes or DNA have superior and unexpected properties from the prior art will be helpful in that regard.

Obtaining patent protection for DNA or other self-replicants that have merely been isolated does not appear to be possible in view of the Myriad decision of the Supreme Court. Accordingly, claims to vectors, new constructs, and compositions containing the DNA; methods to produce those constructs; and methods of using the DNA should be considered. In view of the Prometheus decision, care should be taken to avoid the argument that any such method claims are merely an obvious use of a product of nature.

It seems clear that self-replicating technologies are eligible to be patented. However, recent case law holds that such technologies are not eligible if they can be considered to be "products of nature" or they are conventional methods of using products of nature. Self-replicating technology that has been altered from any native state should be eligible to be patented, but such technology must, of course, comply with other patent law requirements; that is, it must be new, useful, and not obvious from the prior art. 


\section{$\&_{\mathrm{CSH}}^{\infty} \&$ Cold Spring Harbor

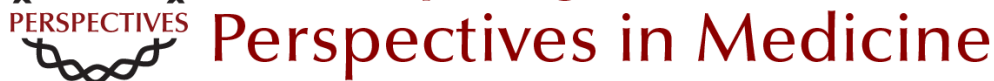

\section{Patentability of Self-Replicating Technologies}

Richard H. Shear

Cold Spring Harb Perspect Med 2015; doi: 10.1101/cshperspect.a021071 originally published online September 25, 2014

\section{Subject Collection Intellectual Property in Molecular Medicine}

Patentability of Stem Cells in the United States Sarah E. Fendrick and Donald L. Zuhn, Jr.

Inventorship and Authorship Antoinette F. Konski and Linda X. Wu

The Patentability of Stem Cells in Australia Jenny Petering and Prue Cowin

Impact of America Invents Act on Biotech Intellectual Property

Amanda Murphy, Michael Stramiello, Jonathan Stroud, et al.

Introduction to Intellectual Property: A U.S.

Perspective

Amanda Murphy, Michael Stramiello, Stacy Lewis, et al.

The Role of Regulatory Agencies and Intellectual Property: Part I

Kevin E. Noonan

Canada's Patented Medicines (Notice of Compliance) Proceedings and Intellectual

Property

Henry Bian and Conor McCourt

Patentability of Genes: A European Union

Perspective

Paul Cole
The Impact of Myriad on the Future Development and Commercialization of DNA-Based Therapies and Diagnostics

Michele Wales and Eddie Cartier

Protecting Traditional Knowledge Related to

Biological Resources: Is Scientific Research

Going to Become More Bureaucratized?

Prashant Reddy and Malathi Lakshmikumaran

Protecting Trade Secrets in Canada

Noel Courage and Janice Calzavara

Inherent Anticipation in the Pharmaceutical and

Biotechnology Industries

Michael Goldman, Georgia Evans and Andrew Zappia

The Role of Regulatory Agencies and Intellectual

Property: Part II

Kevin E. Noonan

Baseball Bats and Chocolate Chip Cookies: The Judicial Treatment of DNA in the Myriad Genetics Litigation lan Binnie and Vanessa Park-Thompson

The Impact of Myriad and Mayo: Will

Advancements in the Biological Sciences $\mathrm{Be}$

Spurred or Disincentivized? (Or Was Biotech

Patenting Not Complicated Enough?) Jennifer Gordon

Trade Secrets in Life Science and Pharmaceutical Companies

Tara Nealey, Ronald M. Daignault and Yu Cai

For additional articles in this collection, see http://perspectivesinmedicine.cshlp.org/cgi/collection/ 